\title{
Leaf area estimation of Burley tobacco
}

\author{
Marcos Toebe ${ }^{1^{*}}$ (i) Francis Junior Soldateli ${ }^{2}$ (i) Rafael Rodrigues de Souza $^{3}$ (i) \\ Anderson Chuquel Mello $^{3}$ (D) Alexandre Segatto ${ }^{4}$ (i)
}

${ }^{1}$ Departamento de Ciências Agronômicas e Ambientais, Universidade Federal de Santa Maria (UFSM), 98400-000, Frederico Westphalen, RS, Brasil. E-mail: m.toebe@gmail.com. *Corresponding author.

${ }^{2}$ Programa de Pós-graduação em Agronomia, Universidade Federal de Santa Maria (UFSM), Santa Maria, RS, Brasil.

${ }^{3}$ Programa de Pós-graduação em Agronomia, Agricultura e Ambiente, Universidade Federal de Santa Maria (UFSM), Frederico Westphalen, RS, Brasil. ${ }^{4}$ Engenheiro Agrônomo, NUFARM BRASIL ${ }^{\circledR}$, Santo Ângelo, RS, Brasil.

ABSTRACT: Leaf area is an important growth variable in agricultural crops and the leaf is the main variable of interest in the tobacco industry. So, the aim of this scientific research was to estimate the Burley tobacco leaf area by linear dimensions of the leaves and to determine which mathematical model is more adequate for this purpose. Two experiments were carried out with Burley tobacco, cultivar DBH 2252, in 2016/2017 and 2018/2019 agricultural years, respectively, in the municipalities of Itaqui and Vanini - RS - Brazil. In 600 leaves were measured length $(L)$, width $(W)$, length $\times$ width product $(L W)$, length/width ratio $(L / W)$ and determined the real leaf area $(L A)$. Four hundred and fifty leaves were separated to generate models of the leaf area as a function of linear dimension and the other 150 leaves were used for model's validation. The power model $L A=0.5037 L W^{1.04435}\left(R^{2}=0.9960\right)$ is the most adequate for Burley tobacco 'DBH 2252 ' leaf area estimation. Alternatively, the models $L A=2.0369 W^{1.8619}\left(R^{2}=0.9796\right)$ and $L A=0.1222 L^{2.2771}\left(R^{2}=0.9738\right)$ based on width and length, respectively, can be used when only one leaf dimension is measured.

Key words: Nicotiana tabacum L., image processing, mathematical models.

Estimativa da área foliar de tabaco do tipo Burley

RESUMO: A área foliar é uma importante variável de crescimento em culturas agrícolas, sendo a folha a principal variável de interesse na indústria do tabaco. Assim, o objetivo deste estudo científico foi determinar a área foliar de tabaco tipo Burley por meio de dimensões lineares da folha e determinar qual modelo matemático é mais adequado para essa finalidade. Dois experimentos foram conduzidos com tabaco tipo Burley, cultivar DBH 2252, nos anos agrícolas de 2016/2017 e 2018/2019, respectivamente, nos municípios de Itaqui e Vanini, RS, Brasil. Em 600 folhas foram medidos o comprimento $(L)$, a largura $(W)$, o produto comprimento $\times$ largura $(L W)$, a razão comprimento/largura $(L / W)$ e determinada a área foliar real (LA). Foram separadas 450 folhas para a geração de modelos de estimativa de área foliar em função da dimensão linear e 150 folhas foram utilizadas para a validação dos modelos. O modelo LA =0,5037LW $W^{1,04435}\left(R^{2}=0,9960\right)$ é adequado para a estimação da área foliar de tabaco Burley cultivar DBH 2252. Alternativamente, os modelos $L A=2,0369 W^{1,8619}\left(R^{2}=0,9796\right)$ e $L A=0,1222 L^{2,2771}$ $\left(R^{2}=0,9738\right)$ baseados na largura e comprimento, respectivamente, podem ser utilizados quando apenas uma dimensão da folha é medida. Palavras-chave: Nicotiana tabacum L., processamento de imagens, modelos matemáticos.

\section{INTRODUCTION}

Tobacco (Nicotiana tabacum L.) is a non-food crop that has worldwide economic relevance (DRESCHER et al., 2011). Its use results from transformation of the leaves (final product), previously selected and classified according to their quality, by the tobacco industry. According to data from AFUBRA (2019), the crop covers 149 thousand producing families in Brazilian southern region, providing 105 thousand seasonal jobs, mainly during the harvest period. The planted area of tobacco in Brazilian southern region was 297,460 hectares in the $2017 / 2018$ harvest with revenues of approximately 0.57 billion dollars in current values.

The leaf area is an important index to reflect on the growing condition of tobacco (WANG et al., 2015) and is the main component of tobacco crop (MAW \& MULLINIX, 1992; BOZHINOVA, 2006). The leaf area index directly affects the photosynthetic 
efficiency of the crops and is related to numerous ecophysiological processes in plant growth and yield (MOUSTAKAS \& NTZANIS, 1998; TAN et al., 2018). According to LIU et al. (2018), the leaf size is an important factor contributing to the photosynthetic capability and affects various agronomic traits. In this sense, TANG et al. (2018) highlighted that leaf size is the major determinant of the architecture and productive potential of many crops. Monitoring the evolution of the leaf area over time enables the evaluation of balanced vegetative growth (SFICAS \& ANTONIOU, 1989; BOZHINOVA, 2006). Studies that allow knowledge of the morphological characteristics, such as the leaf area, are still scarce in some crops and are important for physiologists, ecologists, technicians and farmers.

Leaf area measurement can be costly, timeconsuming and destructive, depending on the direct or indirect method used. Among the non-destructive (indirect) methods, those obtained from the dimensions of the leaf members with the generation of mathematical models that allow the prediction of the leaf area stand out (MALDANER et al., 2009). The use of these models allowed successive leaf measurements without harming the crop, with efficient estimates of the leaf area of damaged and intact limbs. Such models can be used in the field by farmers, extensionists and consultants, without needing to purchase sophisticated devices to determine the leaf area, allowing the crop to be quickly, inexpensively, accurately and non-destructively monitored (TOEBE et al., 2012; 2019; CARGNELUTTI FILHO et al., 2015a; b). Mathematical models have been proposed in crops to estimate leaf area, such as sunflower (MALDANER et al., 2009), coffee (ANTUNES et al., 2008; UNIGARRO-MUÑOZ et al., 2015), rose (ROUPHAEL et al., 2010), snap bean (TOEBE et al., 2012), jatropha (POMPELLI et al., 2012), gladiolus (SCHWAB et al., 2014), canola (CARGNELUTTI FILHO et al., 2015a), jack bean (CARGNELUTTI FILHO et al., 2015b), Vitis vinifera L. (BUTTARO et al., 2015), velvet bean (CARGNELUTTI FILHO et al., 2018) and squash (TOEBE et al., 2019).

In most of the above-cited crops, the leaf is not the main product of interest. Conversely, leaf is the main commercial product of tobacco (BOZHINOVA, 2006). Therefore, leaf area modeling becomes necessary in the crop. In this sense, mathematical models have been created by variety, leaf position, nitrogen treatments and growth stages (MAW \& MULLINIX, 1992; MOUSTAKAS \& NTZANIS, 1998; BOZHINOVA, 2006). In general, the models presented in the literature for tobacco are linear considering the length $\times$ width multiplication and correction coefficient (MAW \& MULLINIX 1992; MOUSTAKAS \& NTZANIS 1998; BOZHINOVA 2006). MAW \& MULLINIX (1992) tested linear and more complex models and concluded that the simplest models provided considerable precision. Posteriorly, $\mathrm{OH}$ et al. (2001) proposed a geometric method of tobacco leaf area estimation by asymptotic curves. Models for Burley tobacco genotypes used in Brazil were not reported in the literature. Thus, the aim of this scientific research was to estimate the leaf area of Burley tobacco 'DBH 2252' by linear dimensions of the leaves and to determine which mathematical model is more adequate for this purpose.

\section{MATERIALS AND METHODS}

Two experiments were carried out with Burley tobacco (Nicotiana tabacum L.), cultivar DBH 2252, in the municipalities of Itaqui - RS Brazil and Vanini - RS - Brazil. The first experiment was conducted in the 2016/2017 agricultural year "in experimental station" of the Federal University of Pampa - campus Itaqui, municipality of Itaqui -RS, located at $29^{\circ} 09^{\prime} 21^{\prime \prime}$ S latitude, $56^{\circ} 33^{\prime} 02^{\prime \prime} \mathrm{W}$ longitude and $74 \mathrm{~m}$ altitude, with soil classified as Haplic Plinthosol (SANTOS et al., 2013), Cfa subtropical climate by Köppen climate classification, annual average temperature between 20.1 and $21.0{ }^{\circ} \mathrm{C}$ and precipitation between 1600 and $1700 \mathrm{~mm}$ (WREGE et al., 2012). The second experiment was carried out in the 2018/2019 agricultural year in a commercial field in the municipality of Vanini - RS, located at $28^{\circ} 48^{\prime} 82^{\prime}$ 'S latitude, 51 ${ }^{\circ} 85^{\prime} 34^{\prime \prime} \mathrm{W}$ longitude and $757 \mathrm{~m}$ altitude, with soil classified as Haplic Nitosol (SANTOS et al., 2013), Cfb warm temperate climate by Köppen climate classification, annual average temperature between 16.1 and $17.0^{\circ} \mathrm{C}$ and precipitation between 1700 and $1800 \mathrm{~mm}$ (WREGE et al., 2012).

In the first experiment, Burley tobacco 'DBH 2252' seeds were sown on June $18^{\text {th }}, 2016$ in 200-cell expanded polystyrene trays, with MacPlant ${ }^{\mathbb{R}}$ commercial substrate in protected environment using the floating system for irrigation. Seedlings were transplanted on September $17^{\text {th }}, 2016$, to five beds $53 \mathrm{~m}$ long, $1.20 \mathrm{~m}$ wide and $0.35 \mathrm{~m}$ high, when the seedlings had six expanded leaves. In each bed, the seedlings were transplanted with $0.70 \mathrm{~m}$ spacing between plants, resulting in 75 plants for each bed, 375 plants in total and a final population of 11905 plants $\mathrm{ha}^{-1}$. The fertilization was performed according to crop recommendations (CQFS, 2016), with 60 $\mathrm{kg} \mathrm{ha}^{-1}$ of $\mathrm{N}, 120 \mathrm{~kg} \mathrm{ha}^{-1}$ of $\mathrm{P}_{2} \mathrm{O}_{5}$, and $100 \mathrm{~kg} \mathrm{ha}^{-1}$ of 
$\mathrm{K}_{2} \mathrm{O}$. In addition, topdressing fertilization was split into one application of $100 \mathrm{~kg} \mathrm{ha}^{-1}$ of $\mathrm{K}_{2} \mathrm{O}$ and four applications of $45 \mathrm{~kg} \mathrm{ha}^{-1}$ of $\mathrm{N}$.

In the second experiment, Burley tobacco 'DBH 2252' seeds were sown on June $20^{\text {th }}, 2018$ in 200-cell expanded polystyrene trays, using MacPlant ${ }^{\circledR}$ substrate. The transplant occurred on September $12^{\text {th }}, 2018$, when the seedlings had six expanded leaves. A spacing of $1.20 \mathrm{~m}$ between beds and $0.50 \mathrm{~m}$ between plants was used, with a final population of 16667 plants ha-1. In both experiments, the other cultural treatments including fertilizer doses were similar; however, soil conditions and prior area management were different.

To determine the leaf area, 600 expanded leaves were collected, being 500 leaves and 100 leaves sampled in the first and second experiments, respectively. In the first experiment, at $67,76,87,95$ and 104 days after transplantation, 100 leaves were randomly collected in the experimental area, every collection day. In the second experiment, 100 leaves were collected at 110 days after transplantation, in nine hectares of tobacco cultivation. The decision to collect leaves at different stages of development within the same experiment (first experiment) and; additionally, leaves from a commercial field (second experiment) in different agricultural years, locations and soil conditions aimed to ensure the wide applicability of the models generated. Length (L) and width (W) were measured in each leaf (Figure 1). Then, the length $\times$ width product $(\mathrm{LW})$ and the length/width ratio $(\mathrm{L} / \mathrm{W})$ were calculated. After, the real leaf area (LA) of each leaf was determined through digital images. For this, leaves were scanned with a resolution of $300 \mathrm{dpi}$ and these digital images were processed with Digimizer v.4.5.2 ${ }^{\circledR}$ software (MEDCALC SOFTWARE, 2018) for real leaf area quantification.

From each collection day, 75 leaves were randomly selected for generation and 25 for validation of the models. So, from the 600 measured leaves, 450 leaves (75\% of leaves) were separated to generate models and 150 leaves (25\% of leaves) to validation of the models. The number of leaves used in the model's generation is higher than the minimum number recommended in the literature in researches of sample sizing ( $n$ ) for the model's generation of leaf area estimation in coffee $(n=$ 200 leaves, ANTUNES et al., 2008), jatropha ( $\mathrm{n}=$ 415 leaves, POMPELLI et al., 2012), jack bean (n = 200 leaves, CARGNELUTTI FILHO et al., 2015b) and velvet bean $(\mathrm{n}=240$ leaves, CARGNELUTTI FILHO et al., 2018).
Position, variability and distribution measures for all variables (L, W, LW, L/W and LA) were calculated in leaves used for the model's generation and validation. With all variables, frequency histograms and scatter plots (Figure 2) were constructed. Then, LA was modeled in function of $\mathrm{L}, \mathrm{W}$ or $\mathrm{LW}$ by linear $(\mathrm{LA}=\mathrm{a}+\mathrm{bx})$, quadratic $\left(\mathrm{LA}=\mathrm{a}+\mathrm{bx}+\mathrm{cx}^{2}\right)$, and power $\left(\mathrm{LA}=\mathrm{ax}^{\mathrm{b}}\right)$ models. In linear and quadratic models, the intercept was equals to zero (SCHWAB et al., 2014) and in the models using the LW product of the leaf, were performed the diagnosis of collinearity based on the variance inflation factor (ROUPHAEL et al., 2010; BUTTARO et al., 2015).

The validation of the models was performed based on the 150 values of leaf area estimated by the model $\left(\mathrm{LAE}_{\mathrm{i}}\right)$ and 150 observed values $\left(\mathrm{LA}_{\mathrm{i}}\right)$. Validation procedures and criteria for selecting the best models were carried out according to the procedures described by TOEBE et al. (2012). All statistical analyzes were performed using Microsoft Office Excel ${ }^{\mathbb{B}}$ application and frequency histogram and scatter plots were performed in Rsoftware(RDEVELOPMENTCORETEAM, 2020).

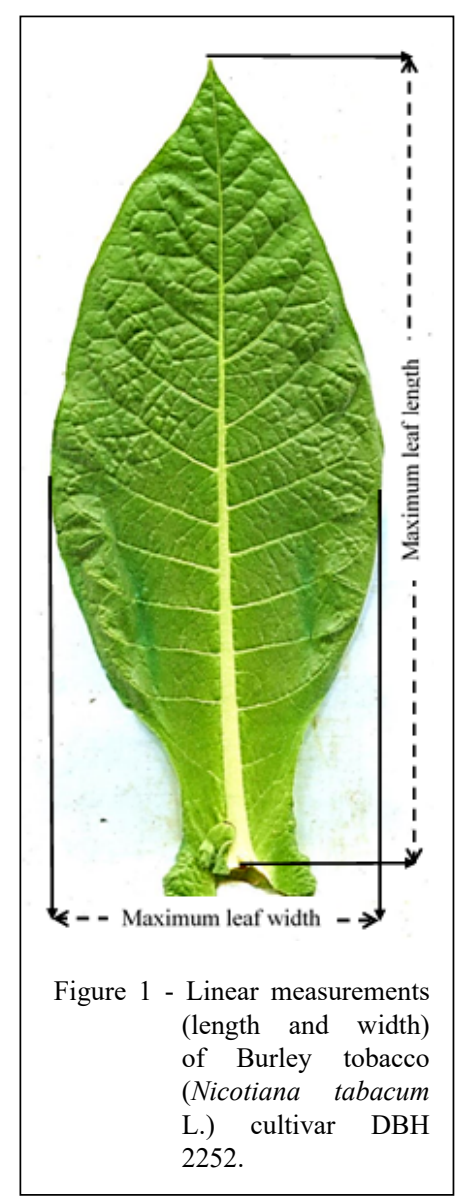

Ciência Rural, v.51, n.1, 2021. 


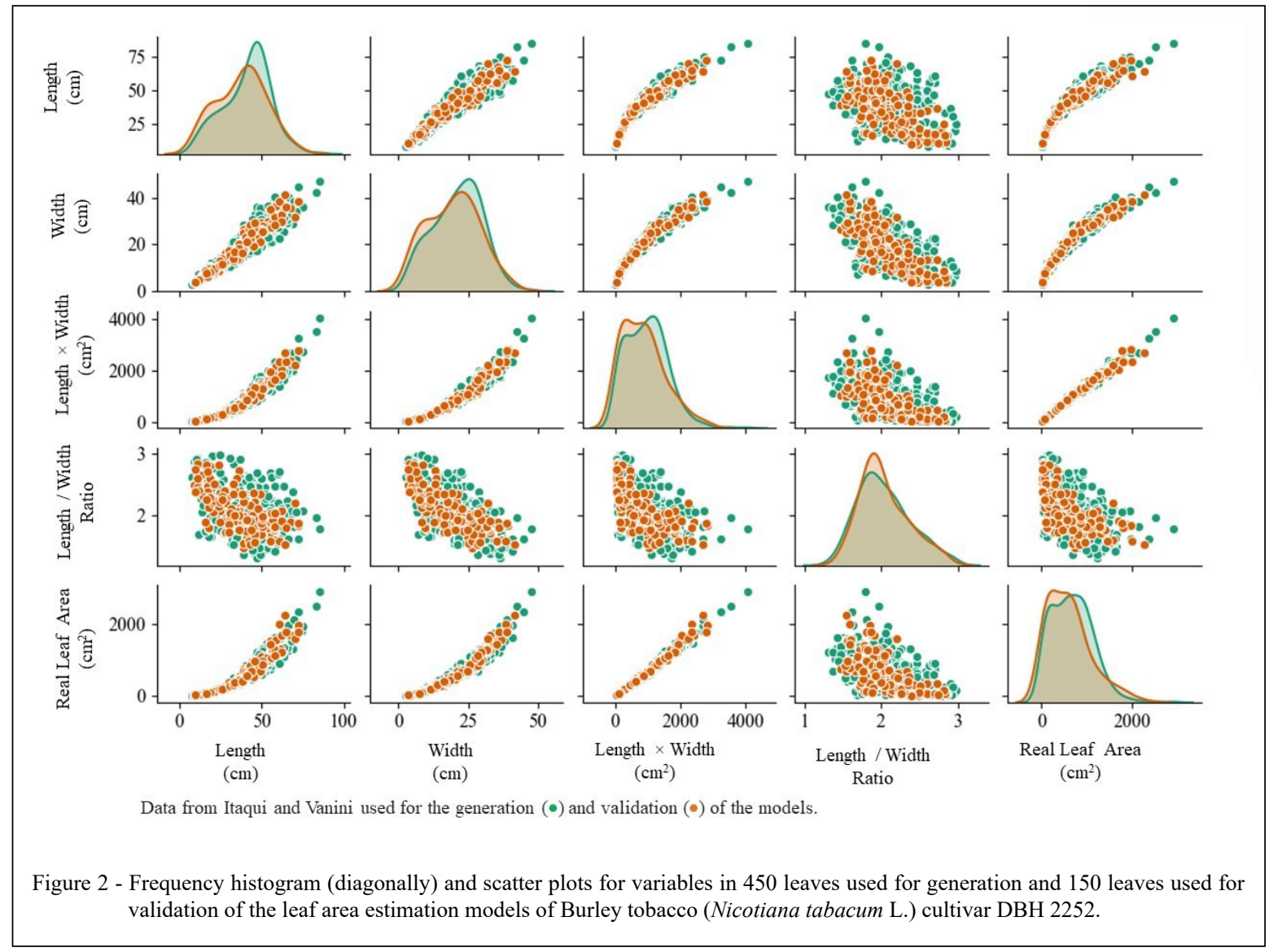

\section{RESULTS AND DISCUSSION}

In most collections, non-significant asymmetry deviations were observed, especially for the length (L) and width (W) variables (Table 1). In the last evaluations and in the general data for the model's generation and validation, positive asymmetry for the length $\times$ width product (LW) and real leaf area (LA) was identified. Such asymmetry deviations can be explained by the high number of observations and the occurrence of some large leaves (with a great LW and LA). Regarding kurtosis, most of the significant deviations were negative, indicating platykurtic patterns, with a higher concentration of data at the extremities. However, in the general database used in the construction of the model, the pattern for LW and RA was leptokurtic, indicating a higher concentration of data in the central region. Such significant deviations also can be explained by the high number of observations that impact on statistical significance in the t-test.

In the generation and validation data, leaves of wide size spectrum were used $(7.30 \mathrm{~cm} \leq$ length $\leq 85.20 \mathrm{~cm}, 2.80 \mathrm{~cm} \leq$ width $\leq 47.60 \mathrm{~cm}, 20.44$ $\mathrm{cm}^{2} \leq$ length $\times$ width $\leq 4055.52 \mathrm{~cm}^{2}$, and $11.20 \mathrm{~cm}^{2} \leq$ real leaf area $\leq 2893.62 \mathrm{~cm}^{2}$ ) (Table 1). In McN-944 tobacco genotype, MOUSTAKAS \& NTZANIS (1998) verified in three agricultural years $(1994,1995$ and 1996) leaves with length between 13.0 to $70.0 \mathrm{~cm}$, width between 5.0 to $34.0 \mathrm{~cm}$ and leaf area between 78.0 to $1100.0 \mathrm{~cm}^{2}$. The leaves used in the model's generation and validation presented high values of variation coefficient $(15.37 \%$ $\leq \mathrm{CV} \leq 78.85 \%$ - Table 1$)$. In this sense, the use of leaves with large size variability is important for the generating and validating of models with large use possibility. Lowest values of variation coefficient (CV) in the model's generation and validation were observed for $\mathrm{L}$ and $\mathrm{W}(34.87 \% \leq \mathrm{CV} \leq 46.93 \%)$ compared to that for LW and LA $(64.41 \% \leq \mathrm{CV} \leq$ $78.85 \%$ ). Similar patterns have already been described in other LA estimation studies (TOEBE et al., 2012; 2019; CARGNELUTTI FILHO et al., 2015a). So, it can be concluded that the wide variability of leaf size, besides the collection in times and places contributed to the data adequacy of the proposed study. 
Table 1 - Descriptive statistics for variables of leaves used in the model's generation and validation of leaf area estimation in Burley tobacco (Nicotiana tabacum L.), cultivar DBH 2252.

\begin{tabular}{|c|c|c|c|c|c|c|c|c|}
\hline \multirow[t]{2}{*}{ Variable $^{(\mathrm{a})}$} & \multicolumn{8}{|c|}{ 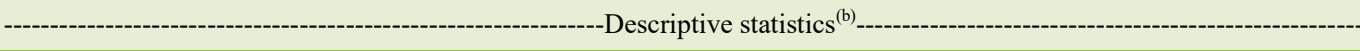 } \\
\hline & Min & Max & Mean & SD & $\mathrm{CV}$ & SE & Asym $^{(\mathrm{c})}$ & Kurt $^{(\mathrm{d})}$ \\
\hline \multicolumn{9}{|c|}{ - } \\
\hline $\mathrm{L}(\mathrm{cm})$ & 7.30 & 51.70 & 32.00 & 13.01 & 40.66 & 1.30 & $-0.40^{\mathrm{ns}}$ & $-1.19^{*}$ \\
\hline $\mathrm{W}(\mathrm{cm})$ & 2.80 & 36.40 & 18.20 & 9.51 & 52.27 & 0.95 & $-0.09^{\mathrm{ns}}$ & $-1.18^{*}$ \\
\hline $\mathrm{LW}\left(\mathrm{cm}^{2}\right)$ & 20.44 & 1806.42 & 701.67 & 515.26 & 73.43 & 51.53 & $0.26^{\mathrm{ns}}$ & $-1.09^{*}$ \\
\hline $\mathrm{L} / \mathrm{W}$ & 1.30 & 2.88 & 1.95 & 0.40 & 20.61 & 0.04 & $0.61^{*}$ & $-0.62^{\mathrm{ns}}$ \\
\hline $\operatorname{LA}\left(\mathrm{cm}^{2}\right)$ & 11.20 & 1320.48 & 475.57 & 364.48 & 76.64 & 36.45 & $0.37^{\mathrm{ns}}$ & $-0.95^{*}$ \\
\hline \multicolumn{9}{|c|}{ - } \\
\hline $\mathrm{L}(\mathrm{cm})$ & 9.90 & 58.50 & 36.95 & 13.46 & 36.42 & 1.35 & $-0.47^{*}$ & $-0.84^{\mathrm{ns}}$ \\
\hline $\mathrm{W}(\mathrm{cm})$ & 3.50 & 40.70 & 20.12 & 9.69 & 48.17 & 0.97 & $-0.14^{\mathrm{ns}}$ & $-1.08^{*}$ \\
\hline $\mathrm{LW}\left(\mathrm{cm}^{2}\right)$ & 35.64 & 2356.53 & 869.03 & 596.31 & 68.62 & 59.63 & $0.30^{\mathrm{ns}}$ & $-0.84^{\mathrm{ns}}$ \\
\hline $\mathrm{L} / \mathrm{W}$ & 1.42 & 2.92 & 2.02 & 0.41 & 20.47 & 0.04 & $0.62^{*}$ & $-0.68^{\mathrm{ns}}$ \\
\hline $\mathrm{LA}\left(\mathrm{cm}^{2}\right)$ & 20.76 & 1622.51 & 602.31 & 428.64 & 71.17 & 42.86 & $0.34^{\mathrm{ns}}$ & $-0.88^{\mathrm{ns}}$ \\
\hline \multicolumn{9}{|c|}{----- } \\
\hline $\mathrm{L}(\mathrm{cm})$ & 14.70 & 62.10 & 42.36 & 11.00 & 25.96 & 1.10 & $-0.65^{*}$ & $-0.37^{\mathrm{ns}}$ \\
\hline $\mathrm{W}(\mathrm{cm})$ & 6.30 & 36.90 & 22.10 & 6.87 & 31.10 & 0.69 & $-0.48^{*}$ & $-0.58^{\mathrm{ns}}$ \\
\hline $\mathrm{LW}\left(\mathrm{cm}^{2}\right)$ & 92.61 & 2291.49 & 1010.18 & 497.65 & 49.26 & 49.77 & $-0.02^{\mathrm{ns}}$ & $-0.67^{\mathrm{ns}}$ \\
\hline $\mathrm{L} / \mathrm{W}$ & 1.68 & 2.34 & 1.96 & 0.16 & 8.15 & 0.02 & $0.73^{*}$ & $-0.40^{\mathrm{ns}}$ \\
\hline $\mathrm{LA}\left(\mathrm{cm}^{2}\right)$ & 54.92 & 1647.06 & 692.03 & 356.61 & 51.53 & 35.66 & $0.03^{\mathrm{ns}}$ & $-0.68^{\mathrm{ns}}$ \\
\hline \multicolumn{9}{|c|}{ - } \\
\hline $\mathrm{L}(\mathrm{cm})$ & 8.90 & 59.90 & 39.58 & 14.71 & 37.18 & 1.47 & $-0.49^{*}$ & $-1.14^{*}$ \\
\hline $\mathrm{W}(\mathrm{cm})$ & 3.10 & 38.30 & 19.60 & 9.56 & 48.78 & 0.96 & $0.06^{\mathrm{ns}}$ & $-1.22^{*}$ \\
\hline $\mathrm{LW}\left(\mathrm{cm}^{2}\right)$ & 27.59 & 2198.42 & 909.38 & 637.99 & 70.16 & 63.80 & $0.24^{\mathrm{ns}}$ & $-1.20^{*}$ \\
\hline $\mathrm{L} / \mathrm{W}$ & 1.50 & 2.87 & 2.17 & 0.34 & 15.75 & 0.03 & $-0.08^{\mathrm{ns}}$ & $-0.96^{*}$ \\
\hline $\mathrm{LA}\left(\mathrm{cm}^{2}\right)$ & 18.84 & 1641.23 & 637.63 & 466.10 & 73.10 & 46.61 & $0.37^{\mathrm{ns}}$ & $-1.02^{*}$ \\
\hline \multicolumn{9}{|c|}{ 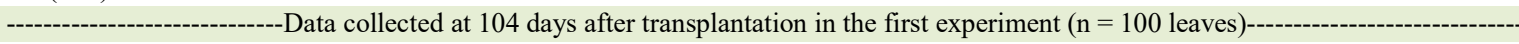 } \\
\hline $\mathrm{L}(\mathrm{cm})$ & 12.00 & 69.90 & 40.76 & 14.40 & 35.33 & 1.44 & $0.04^{\mathrm{ns}}$ & $-0.70^{\mathrm{ns}}$ \\
\hline $\mathrm{W}(\mathrm{cm})$ & 6.50 & 41.70 & 21.62 & 8.37 & 38.74 & 0.84 & $0.35^{\mathrm{ns}}$ & $-0.61^{\mathrm{ns}}$ \\
\hline $\mathrm{LW}\left(\mathrm{cm}^{2}\right)$ & 85.20 & 2698.14 & 995.29 & 673.23 & 67.64 & 67.32 & $0.78^{*}$ & $-0.20^{\mathrm{ns}}$ \\
\hline $\mathrm{L} / \mathrm{W}$ & 1.54 & 2.32 & 1.91 & 0.18 & 9.56 & 0.02 & $0.02^{\mathrm{ns}}$ & $-0.66^{\mathrm{ns}}$ \\
\hline $\mathrm{LA}\left(\mathrm{cm}^{2}\right)$ & 43.99 & 2258.41 & 697.63 & 509.07 & 72.97 & 50.91 & $1.03^{*}$ & $0.59^{\mathrm{ns}}$ \\
\hline \multicolumn{9}{|c|}{ 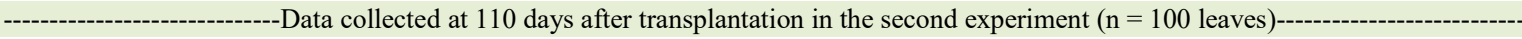 } \\
\hline $\mathrm{L}(\mathrm{cm})$ & 11.30 & 85.20 & 50.25 & 14.45 & 28.77 & 1.45 & $-0.19^{\mathrm{ns}}$ & $0.22^{\mathrm{ns}}$ \\
\hline $\mathrm{W}(\mathrm{cm})$ & 4.60 & 47.60 & 23.15 & 8.17 & 35.30 & 0.82 & $0.40^{\mathrm{ns}}$ & $0.70^{\mathrm{ns}}$ \\
\hline $\mathrm{LW}\left(\mathrm{cm}^{2}\right)$ & 51.98 & 4055.52 & 1272.49 & 764.78 & 60.10 & 76.48 & $1.14^{*}$ & $1.58^{*}$ \\
\hline $\mathrm{L} / \mathrm{W}$ & 1.62 & 2.98 & 2.24 & 0.31 & 13.99 & 0.03 & $0.41^{\mathrm{ns}}$ & $-0.52^{\mathrm{ns}}$ \\
\hline $\operatorname{LA}\left(\mathrm{cm}^{2}\right)$ & 37.14 & 2893.62 & 884.22 & 531.99 & 60.16 & 53.20 & $1.23^{*}$ & $2.04^{*}$ \\
\hline \multicolumn{9}{|c|}{ 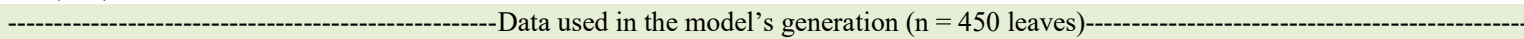 } \\
\hline $\mathrm{L}(\mathrm{cm})$ & 7.30 & 85.20 & 41.15 & 14.35 & 34.87 & 0.68 & $-0.25^{*}$ & $-0.21^{\mathrm{ns}}$ \\
\hline $\mathrm{W}(\mathrm{cm})$ & 2.80 & 47.60 & 21.19 & 8.74 & 41.24 & 0.41 & $-0.11^{\mathrm{ns}}$ & $-0.53^{*}$ \\
\hline $\mathrm{LW}\left(\mathrm{cm}^{2}\right)$ & 20.44 & 4055.52 & 987.74 & 636.17 & 64.41 & 29.99 & $0.73^{*}$ & $1.20^{*}$ \\
\hline $\mathrm{L} / \mathrm{W}$ & 1.30 & 2.98 & 2.04 & 0.35 & 17.00 & 0.02 & $0.52^{*}$ & $-0.26^{\mathrm{ns}}$ \\
\hline $\mathrm{LA}\left(\mathrm{cm}^{2}\right)$ & 11.20 & 2893.62 & 683.03 & 455.19 & 66.64 & 21.46 & $0.79^{*}$ & $1.33^{*}$ \\
\hline \multicolumn{9}{|c|}{-Data used in the model's validation $(n=150$ leaves)-- } \\
\hline $\mathrm{L}(\mathrm{cm})$ & 9.20 & 72.30 & 37.82 & 15.11 & 39.95 & 1.23 & $-0.03^{\text {ns }}$ & $-0.67^{\mathrm{ns}}$ \\
\hline $\mathrm{W}(\mathrm{cm})$ & 3.60 & 41.70 & 19.61 & 9.20 & 46.93 & 0.75 & $0.07^{\mathrm{ns}}$ & $-0.77^{*}$ \\
\hline $\mathrm{LW}\left(\mathrm{cm}^{2}\right)$ & 34.04 & 2834.16 & 875.47 & 654.58 & 74.77 & 53.45 & $0.80^{*}$ & $0.20^{\mathrm{ns}}$ \\
\hline $\mathrm{L} / \mathrm{W}$ & 1.47 & 2.84 & 2.04 & 0.31 & 15.37 & 0.03 & $0.68^{*}$ & $-0.11^{\mathrm{ns}}$ \\
\hline $\mathrm{LA}\left(\mathrm{cm}^{2}\right)$ & 18.26 & 2258.41 & 610.50 & 481.40 & 78.85 & 39.31 & $0.99^{*}$ & $0.76^{\mathrm{ns}}$ \\
\hline
\end{tabular}

${ }^{\text {(a) }} \mathrm{L}=$ length; $\mathrm{W}=$ width; $\mathrm{LW}=$ length $\times$ width; $\mathrm{L} / \mathrm{W}=$ length $/$ width ratio; $\mathrm{LA}=$ real leaf area. ${ }^{\text {(b) }}$ Min $=$ minimum; Max $=$ maximum; Mean = mean; $\mathrm{SD}=$ standard deviation; $\mathrm{CV}=$ coefficient of variation; $\mathrm{SE}=$ standard error; Asym $=$ asymmetry; Kurt $=$ kurtosis. ${ }^{(\mathrm{c}) *}$ Asymmetry differs from zero by the t-test at $5 \%$ probability level. ${ }^{\mathrm{ns}}$ non-significant. ${ }^{\text {(d) }}{ }^{*}$ Kurtosis differs from zero by $\mathrm{t}$-test at $5 \%$ probability level. ${ }^{\text {ns }}$ non-significant. 
Linear and nonlinear associations between L, W, LW, L/W and LA were observed in data utilized in the model's generation and validation (Figure 2 and 3). Linear patterns can be observed between $\mathrm{L}$ and $\mathrm{W}$ and between LW and LA. The other associations indicated non-linear relationships. The patterns are similar between the data used in the generation and validation of the models. So, models
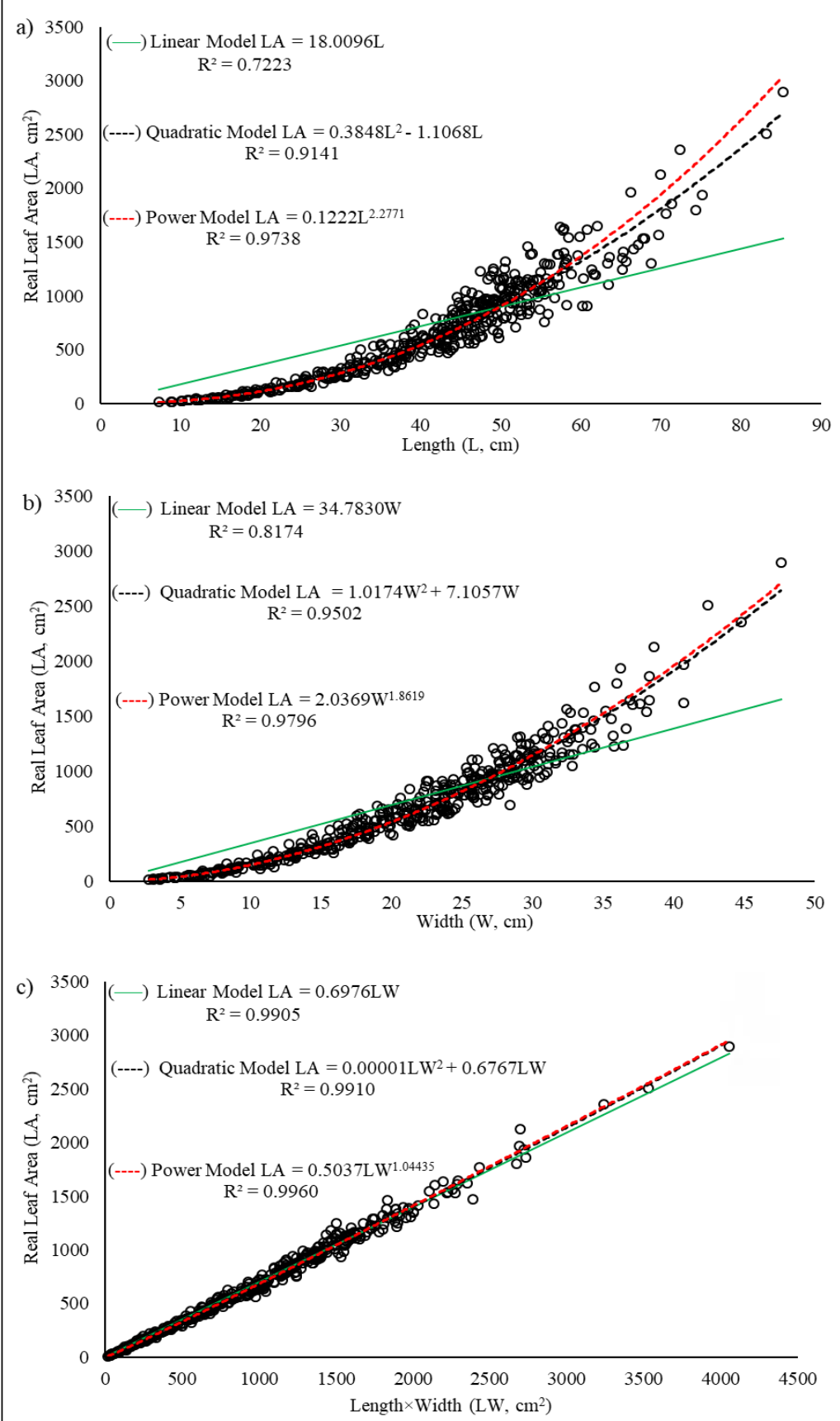

Figure 3 - Linear, quadratic and power models for the real leaf area (LA) estimation as a function of linear dimension: a) Length; b) Width; c) Length $\times$ Width product, generated based on $n=450$ leaves and coefficient of determination $\left(\mathrm{R}^{2}\right)$ in each model for Burley tobacco (Nicotiana tabacum L.) cultivar DBH 2252. 
of different types were generated and validated. If the length is used as the single leaf dimension for the LA estimation, the model $\mathrm{LA}=0.1222 \mathrm{~L}^{2.2771}\left(\mathrm{R}^{2}=0.9738\right)$ presented the best adjustment, followed by the model $\mathrm{LA}=0.3848 \mathrm{~L}^{2}-1.1068 \mathrm{~L}\left(\mathrm{R}^{2}=0.9141\right.$ - Figure $\left.3 \mathrm{a}\right)$. If the width is used as the single leaf dimension for the LA estimation, the model $\mathrm{LA}=2.0369 \mathrm{~W}^{1.8619}\left(\mathrm{R}^{2}=0.9796\right)$ provided the best adjustment, followed by the model $\mathrm{LA}=1.0174 \mathrm{~W}^{2}+7.1057 \mathrm{~W}\left(\mathrm{R}^{2}=0.9502\right.$ - Figure $\left.3 \mathrm{~b}\right)$. For models generated from the $\mathrm{LW}$, the prediction has similarity in the three model types (Figure 3c), being that the power $\left(\mathrm{LA}=0.5037 \mathrm{LW}^{1.04435}, \mathrm{R}^{2}=0.9960\right)$, quadratic $\left(\mathrm{LA}=0.00001 \mathrm{LW}^{2}+0.6767 \mathrm{LW}, \mathrm{R}^{2}=0.9910\right)$, and linear model $\left(\mathrm{LA}=0.6976 \mathrm{LW}, \mathrm{R}^{2}=0.9905\right)$, which presented high reliability.

Mathematical models of LA in function of $\mathrm{L}, \mathrm{W}$, or LW were also generated in sunflower (MALDANER et al., 2009), coffee (ANTUNES et al., 2008; UNIGARRO-MUÑOZ et al., 2015), rose (ROUPHAEL et al., 2010), snap bean (TOEBE et al., 2012), jatropha (POMPELLI et al., 2012), gladiolus (SCHWAB et al., 2014), canola (CARGNELUTTI FILHO et al., 2015a), jack bean (CARGNELUTTI FILHO et al., 2015b), Vitis vinifera L. (BUTTARO et al., 2015), velvet bean (CARGNELUTTI FILHO et al., 2018) and squash (TOEBE et al., 2019). In general, the models presented high prediction capacity and reliability.

The model $\mathrm{LA}=0.6976 \mathrm{LW} \quad\left(\mathrm{R}^{2}=0.9905\right)$ presented high reliability (Figure $3 \mathrm{c}$ ). In this case, the correction factor is 0.6976 multiplied by the LW. In the NC2326 tobacco genotype, MAW \& MULLINIX (1992) identified the need to use a correction factor of 0.56 to 0.61 multiplied by LW, depending on the evaluation year. The authors also reported that the correction coefficient ranged from 0.42 to 0.69 depending on the year and the position of the leaf on the plant. The precision of these models was high $\left(\mathrm{R}^{2} \geq 0.958\right)$. In Burley tobacco, BOZHINOVA (2006) identified the need for multiplication of the LW by correction coefficient from 0.64 to 0.71 depending on genotype and leaf position on the stalk. According to the author, the correction coefficient should be 0.71 for 'Burley 1000' and 0.69 for 'Burley 21' regardless of the stalk position. For 'Burley 1317' the correction coefficient oscillated between 0.64 and 0.68 depending on plant zones. In the McN-944 tobacco genotype, MOUSTAKAS \& NTZANIS (1998) identified the need to use an estimated empirical constant of 0.653 multiplied by LW. According to the authors, no differences were reported in the estimated empirical constant between nitrogen treatments and growth stages, having the model been validated in different years, soil types and growth stages. In the present study, although, the models could be generated by evaluation date, location and year, general models were generated with a greater number of observations, consistency and scenarios. As a result, the good indicators of these models (Figure 3 and Table 2) indicated that they are valid and have greater coverage than models generated for specific conditions, which could limit their use.

Table 2 - Models validation based on indicators: linear coefficient (a), slope coefficient (b), Pearson correlation coefficient (r) and determination coefficient $\left(\mathrm{R}^{2}\right)$, mean absolute error (MAE), root mean square error (RMSE) and d Willmott index (d), calculated between observed and estimated leaf area of 150 leaves of Burley tobacco (Nicotiana tabacum L.), cultivar DBH 2252 .

\begin{tabular}{|c|c|c|c|c|c|c|c|c|}
\hline Model Type & Independent variable & $a^{(a)}$ & $b^{(b)}$ & $r^{(c)}$ & $\mathrm{R}^{2}$ & MAE & RMSE & $\mathrm{d}$ \\
\hline 1) Linear & Length & $356.724^{*}$ & $0.531^{*}$ & $0.94^{*}$ & 0.884 & 204.462 & 254.006 & 0.832 \\
\hline 2) Quadratic & Length & $64.432^{*}$ & $0.870^{*}$ & $0.969^{*}$ & 0.940 & 73.195 & 123.787 & 0.951 \\
\hline 3) Power & Length & $23.466^{\mathrm{ns}}$ & $0.923^{*}$ & $0.968^{*}$ & 0.938 & 71.113 & 122.084 & 0.952 \\
\hline 4) Linear & Width & $292.653^{*}$ & $0.638^{*}$ & $0.959^{*}$ & 0.921 & 173.844 & 208.993 & 0.894 \\
\hline 5) Quadratic & Width & $53.821^{*}$ & $0.921^{*}$ & $0.988^{*}$ & 0.977 & 53.469 & 77.655 & 0.982 \\
\hline 6) Power & Width & $26.093^{*}$ & $0.958^{*}$ & $0.988^{*}$ & 0.977 & 47.975 & 72.976 & 0.983 \\
\hline 7) Linear & Length $\times$ Width & $36.186^{*}$ & $0.941^{*}$ & $0.992^{*}$ & 0.984 & 33.489 & 63.783 & 0.988 \\
\hline 8) Quadratic & Length $\times$ Width & $26.542^{*}$ & $0.950^{*}$ & $0.992^{*}$ & 0.985 & 31.421 & 61.131 & 0.988 \\
\hline 9) Power & Length $\times$ Width & $15.889^{*}$ & $0.962^{*}$ & $0.992^{*}$ & 0.985 & 30.605 & 59.848 & 0.989 \\
\hline
\end{tabular}

${ }^{(a)}$ Linear coefficient differs from zero, according to the $\mathrm{t}$ test at $\mathrm{P}<0.05$. ${ }^{\mathrm{ns}}$ non-significant. ${ }^{(\mathrm{b})}$ Slope coefficient differs from one, according to the $\mathrm{t}$ test at $\mathrm{p}<0.05$. ${ }^{\mathrm{ns}}$ non-significant. ${ }^{(\mathrm{c})}$ Pearson correlation coefficient differs from zero, according to the $\mathrm{t}$ test at $\mathrm{p}<0.05$. ${ }^{\mathrm{n} s}$ non-significant. 
Regardless of the dimension considered (L, W, or LW), the power model provided the best adjustment $\left(0.9738 \leq \mathrm{R}^{2} \leq 0.9960\right.$ - Figure $\left.3 \mathrm{a}, \mathrm{b}, \mathrm{c}\right)$. The superiority of this model's type, especially when only one dimension of the leaf is considered, has been described in the literature in other crops, as coffee (ANTUNES et al., 2008), sunflower (MALDANER et al., 2009), jatropha (POMPELLI et al., 2012), gladiolus (SCHWAB et al., 2014), canola (CARGNELUTTI FILHO et al., 2015a), jack bean (CARGNELUTTI FILHO et al., 2015b) and velvet bean (CARGNELUTTI FILHO et al., 2018). In the validation phase, the power models based on $\mathrm{L}, \mathrm{W}$ or LW and the linear and quadratic models based on LW presented the best indicators (Table 2). Among these models, the model $\mathrm{LA}=0.5037 \mathrm{LW}^{1.04435}$ was superior in all validation indicatives between $\mathrm{LAE}_{\mathrm{i}}$ and LA. It was verified low collinearity between $\mathrm{L}$ and $\mathrm{W}(\mathrm{VIF}=6.90)$, indicating the absence of collinearity problems (ROUPHAEL et al., 2010; BUTTARO et al., 2015). So, there is no problem to use LW in the generation of Burley tobacco leaf area estimation models. Thus, the power model $\mathrm{LA}=0.5037 \mathrm{LW}^{1.04435}\left(\mathrm{R}^{2}=0.9960\right)$ is recommended for LA estimation of Burley tobacco 'DBH 2252', considering the low collinearity and the good adjustments previously described for this model. If the researcher chooses to evaluate only one leaf dimension, can use the models $\mathrm{LA}=2.0369 \mathrm{~W}^{1.8619}$ $\left(\mathrm{R}^{2}=0.9796\right) \quad$ and $\mathrm{LA}=0.1222 \mathrm{~L}^{2.2771} \quad\left(\mathrm{R}^{2}=0.9738\right)$ based on width and length, respectively, which good indicators, being slightly inferior to the power model obtained by the product LW.

\section{CONCLUSION}

The power model $\mathrm{LA}=0.5037 \mathrm{LW}^{1.04435}$ $\left(\mathrm{R}^{2}=0.9960\right)$ is the most adequate for leaf area estimation of Burley tobacco 'DBH 2252'. Alternatively, the models $\mathrm{LA}=2.0369 \mathrm{~W}^{1.8619} \quad\left(\mathrm{R}^{2}=0.9796\right)$ and $\mathrm{LA}=0.1222 \mathrm{~L}^{2.2771}\left(\mathrm{R}^{2}=0.9738\right)$ based on width and length, respectively, can be used when only one leaf dimension is measured.

\section{ACKNOWLEDGMENTS}

To the Conselho Nacional de Desenvolvimento Científico e Tecnológico - CNPq, to the Fundação de Amparo à Pesquisa do Estado do Rio Grande do Sul - FAPERGS, to the Programa de Educação Tutorial - PET and to the Fundação Universidade Federal do Pampa by scholarships. To the FAPERGS/CNPq by financial support (Process number 16/2551-0000257-6 ARD/PPP) and to the Coordenação de Aperfeiçoamento de Pessoal de Nível Superior - CAPES (Brasil - Finance code 001).

\section{DECLARATION OF CONFLICT OF INTERESTS}

The authors declare no conflict of interest. The founding sponsors had no role in the design of the study; in the collection, analyses, or interpretation of data; in the writing of the manuscript, and in the decision to publish the results.

\section{AUTHORS' CONTRIBUTIONS}

All authors conceived the experiments. FJS, RRS, ACM and AS performed the experiments and data collection. MT supervised and coordinated the experiments. All authors performed the image processing. MT performed the statistical analyses. MT and RRS prepared the draft of the manuscript. All authors critically revised the manuscript and approved of the final version.

\section{REFERENCES}

AFUBRA - Associação dos fumicultores do Brasil. Fumicultura no Brasil. 2019. Available from: <https://afubra.com.br/ fumicultura-brasil.html>. Accessed: Oct. 07, 2019.

ANTUNES, W. C. et al. Allometric models for non-destructive leaf area estimation in coffee (Coffea arabica and Coffea canephora). Annals of Applied Biology, v.153, p.33-40, 2008. Available from: $<$ http://dx.doi.org/10.1111/j.1744-7348.2008.00235.x>. Accessed: Jun. 24, 2020. doi: 10.1111/j.1744-7348.2008.00235.x.

BOZHINOVA, R. Coefficients for determination of the leaf area in three burley tobacco varieties. Journal of Central European Agriculture, v.7, p.7-12, 2006. Available from: <https://jcea. agr.hr/en/issues/article/304>. Accessed: Jan. 24, 2020. doi: 10.5513/jcea.v7i1.349.

BUTTARO, D. et al. Simple and accurate allometric model for leaf area estimation in Vitis vinifera L. genotypes. Photosynthetica, v.53, p.342-348, 2015. Available from: <http://dx.doi.org/10.1007/s11099015-0117-2>. Accessed: Jan. 24, 2020. doi: 10.1007/s11099-015-0117-2.

CARGNELUTTI FILHO, A. et al. Leaf area estimation of canola by leaf dimensions. Bragantia, v.74, p.1-8, 2015a. Available from: $<$ http://dx.doi.org/10.1590/1678-4499.0388>. Accessed: Jan. 24, 2020. doi: 10.1590/1678-4499.0388.

CARGNELUTTI FILHO, A. et al. Number of leaves for modelling the leaf area of velvet bean according to leaf dimensions. Revista de Ciências Agroveterinárias, v.17, p.571-578, 2018. Available from: $<$ http://dx.doi.org/10.5965/223811711732018571>. Accessed: Jun. 24, 2020. doi: $10.5965 / 223811711732018571$.

CARGNELUTTI FILHO, A. et al. Number of leaves needed to model leaf area in jack bean plants using leaf dimensions. Bioscience Journal, v.31, p.1651-1662, 2015b. Available from: $<$ http://www.seer.ufu.br/index.php/biosciencejournal/article/ view/26135>. Accessed: Jun. 24, 2020.

CQFS - Comissão de Química e Fertilidade do Solo. Manual de adubação e de calagem para os Estados do Rio Grande do Sul e de Santa Catarina. $10^{\mathrm{a}}$ ed. Porto Alegre: Sociedade Brasileira de Ciência do Solo. 2004. 400p.

DRESCHER, M. S. et al. Epigeic fauna in production systems of Nicotiana tabacum L. Revista Brasileira de Ciência do 
Solo, v.35, p.1499-1507, 2011. Available from: <http://dx.doi. org/10.1590/S0100-06832011000500004>. Accessed: Jan. 24, 2020. doi: $10.1590 / \mathrm{S} 0100-06832011000500004$.

MALDANER, I. C. et al. Models for estimating leaf area in sunflower. Ciência Rural, v.39, p.1356-1361, 2009. Available from: <http://dx.doi.org/10.1590/S0103-84782009000500008>. Accessed: Jan. 24, 2020. doi: 10.1590/S0103-84782009000500008.

MAW, B. W.; MULLINIX, B. Comparing six models of various complexity for calculating leaf area from measurements of leaf width and legth. Tobacco Science, v.36, p.40-42, 1992.

MEDCALC SOFTWARE. Digimizer image analysis software manual. Belgium. 2018. Available from: <http://www.digimizer. com/manual/index.php>. Accessed: Oct. 07, 2019.

MOUSTAKAS, N. K.; NTZANIS, H. Estimating flue-cured tobacco leaf area from linear measurements, under Mediterranean conditions. Agricoltura Mediterranea, v.128, p.226-231, 1998.

LIU, Y. et al. Identification of QTL for flag leaf length in common wheat and their pleiotropic effects. Molecular Breeding, v.38, p.1-11, 2018. Available from: $<$ https://doi.org/10.1007/s11032-017-0766-x>. Accessed: Jun. 24, 2020. doi: 10.1007/s11032-017-0766-x.

$\mathrm{OH}, \mathrm{I}$. H. et al. Measuring tobacco leaf area by numerical integration of asymptotic regression equations. Applied Engineering in Agriculture, v.17, p.107-109, 2001.

POMPELLI, M. F. et al. Allometric models for non-destructive leaf area estimation of Jatropha curcas. Biomass and Bioenergy, v.36, p.77-85, 2012. Available from: <http://dx.doi.org/10.1016/j. biombioe.2011.10.010>. Accessed: Jun. 24, 2020. doi: 10.1016/j. biombioe.2011.10.010.

R DEVELOPMENT CORE TEAM. R: A Language and Environment for Statistical Computing. Vienna: R Foundation for Statistical Computing. Available from: <http://www.R-project. org>. Accessed: Jan. 24, 2020.

ROUPHAEL, Y. et al. Modeling individual leaf area of rose (Rosa hybrida L.) based on leaf length and width measurement. Photosynthetica, v.48, p.9-15, 2010. Available from: <http:// dx.doi.org/10.1007/s11099-010-0003-x>. Accessed: Jan. 24, 2020. doi: 10.1007/s11099-010-0003-x.

SANTOS, H.G. et al. Sistema brasileiro de classificação de solos. Brasília: EMBRAPA, 2013. 353p.

SCHWAB, N. T. et al. Linear dimensions of leaves and its use for estimating the vertical profile of leaf area in gladiolus. Bragantia, v.73, p.97-105, 2014. Available from: <http://dx.doi.org/10.1590/ brag.2014.014>. Accessed: Jan. 24, 2020. doi: 10.1590/ brag.2014.014.

SFICAS, A. G.; ANTONIOU, I. C. Growth and development of the main greek oriental tobacco cultivars. Beiträge zur Tabakforschung International/Contributions to Tobacco Research, v.14, p.177-187, 1989. Available from: $<$ http://dx.doi. org/10.2478/cttr-2013-0598>. Accessed: Jan. 24, 2020. doi: $10.2478 /$ cttr-2013-0598.

TAN, C. et al. Analysis of different hyperspectral variables for diagnosing leaf nitrogen accumulation in wheat. Frontiers in Plant Science, v.9, p.674-685, 2018. Available from: <http:// dx.doi.org/10.3389/fpls.2018.00674>. Accessed: Jun. 03, 2020. doi: $10.3389 /$ fpls.2018.00674.

TANG, X. et al. Genetic dissection and validation of candidate genes for flag leaf size in rice (Oryza sativa L.). Theoretical and Applied Genetics, v.131, p.801-815, 2018. Available from: <https://doi.org/10.1007/s00122-017-3036-8>. Accessed: Jun. 24, 2020. doi: 10.1007/s00122-017-3036-8.

TOEBE, M. et al. Leaf area estimation of squash 'Brasileirinha' by leaf dimensions. Ciência Rural, v.49, p.1-11, 2019. Available from: $\quad<$ http://dx.doi.org/10.1590/0103-8478cr20180932>. Accessed: Jan. 24, 2020. doi: 10.1590/0103-8478cr20180932.

TOEBE, M. et al. Leaf area of snap bean (Phaseolus vulgaris L.) according to leaf dimensions. Semina. Ciências Agrárias, v.33, p.2491-2500, 2012. Available from: <http://www.uel.br/revistas/ uel/index.php/semagrarias/article/view/8008>. Accessed: Jan. 24, 2020. doi: 10.5433/1679-0359.2012v33n6Supl1p2491.

UNIGARRO-MUÑOZ, C. A. et al. Estimation of leaf area in coffee leaves (Coffea arabica L.) of the Castillo variety. Bragantia, v.74, p.412-416, 2015. Available from: <http://dx.doi. org/10.1590/1678-4499.0026>. Accessed: Jan. 24, 2020. doi: $10.1590 / 1678-4499.0026$.

WANG, K. et al. The application of high resolution SAR in mountain area of Karst tobacco leaf area index estimation model. Journal of Coastal Research, v.73, p.415-419, 2015. Available from: < https://doi.org/10.2112/SI73-073.1>. Accessed: Jun. 03, 2020. doi: 10.2112/SI73-073.1.

WILlmotT, C. J. On the validation of models. Physical Geography, v.2, p.184-194, 1981. Available from: <http://dx.doi. org/10.1080/02723646.1981.10642213>. Accessed: Jan. 24, 2020. doi: $10.1080 / 02723646.1981 .10642213$.

WREGE, M. S. et al. Atlas climático da Região Sul do Brasil: Estados do Paraná, Santa Catarina e Rio Grande do Sul. $2^{\mathrm{a}}$ ed. Brasília: EMBRAPA, 2012. 333p. 